\title{
Pathogenic p.Cys194Metfs*17 variant argues against TMPRSS3/ GJB2 digenic inheritance of hearing loss
}

\author{
Urszula Lechowicz $^{1}$ - Agnieszka Pollak ${ }^{1} \cdot$ Dominka Oziębło $^{1} \cdot$ Monika Ołdak $^{1}$
}

Received: 27 August 2015/Accepted: 8 September 2015/Published online: 25 September 2015

(C) The Author(s) 2015. This article is published with open access at Springerlink.com

\section{Dear Editor,}

We read with great interest the article "TMPRSS3 mutations in autosomal recessive nonsyndromic hearing loss" by Battelino et al. [1]. Performing targeted next-generation sequencing the authors have identified TMPRSS3 mutations as a frequent cause of autosomal recessive non-syndromic hearing loss (ARNSHL) in Slovenian patients and demonstrated that TMPRSS3 gene analysis should be performed in the first tier of ARNSHL genetic investigations [1]. While this is an interesting and clinically relevant finding, our attention was drawn by the interpretation of the genetic results obtained in one individual of the index family. This patient with profound congenital deafness was identified to be compound heterozygous for c.208delC and c.579dupA mutations in the TMPRSS3 gene (DFNB8/10) and heterozygous for the c.35delG mutation in GJB2 (DFNB1), which is the most common cause of ARNSHL in Caucasian population [2]. Battelino et al. have classified TMPRSS3 3 c.579dupA as a non-pathogenic variant located in the noncoding exon and based on the presence of the two other mutations (c.208delC in TMPRSS3 and c.35delG in GJB2) implied a possible TMPRSS3/GJB2 digenic inheritance of ARNSHL in this family.

It is not clear for us why the authors did not accept TMPRSS3 c.579dupA as a causative variant. We could not

This comment refers to the article available at doi:10.1007/s00405-015-3671-0.

Monika Ołdak

m.oldak@ifps.org.pl

1 Department of Genetics, Institute of Physiology and Pathology of Hearing, M. Mochnackiego 10, 02-042 Warsaw, Poland find the TMPRSS3 reference sequence in the paper by Battelino et al. but based on the nomenclature used (c.579dupA and p.Cys194Metfs*17, rs397517376), we assume that they refer to the NM_024022.2 and NP_076927.1 sequences at the mRNA and protein levels, respectively. According to these sequences c.579dupA localizes to the TMPRSS 3 coding region. This frame-shift variant introduces a premature stop codon, which most probably severely truncates the protein and has a deleterious effect on its function. TMPRSS3 c.579dupA is reported in the Single Nucleotide Polymorphism Database (dbSNP) and ClinVar as pathogenic (http://www.ncbi.nlm.nih.gov/ clinvar/, http://www.ncbi.nlm.nih.gov/projects/SNP/, accessed 08/2015) and our data also support its pathogenic potential (U. Lechowicz [3], manuscript in preparation). Furthermore, two other TMPRSS3 mutations (NM_024022.2:c.582T>A; NP_076927.1:p.C194* and NM_024022.2:c.581G>T; NP_076927.1:p.C194F) were detected in the region corresponding to the same codon position (p.Cys194) in Palestinian and Pakistani families with ARNSHL, respectively [4, 5].

Deafness is an excellent candidate for digenic inheritance with examples for non-syndromic and syndromic hearing loss [6]. Both, GJB2 and TMPRSS3 are expressed in the supporting cells and stria vascularis of the inner ear [7] but except for a frequent co-occurrence of both gene names in scientific articles, in silico analysis does not suggest any functional link between these proteins (STRING 10.0, http://string-db.org/). To the best of our knowledge, there is neither in vivo nor in vitro data supporting the hypothesis of TMPRSS3/GJB2 digenic inheritance of deafness and the results provided by Battelino et al. are, in our opinion, also insufficient to reinforce it. We are strongly convinced that ARNSHL in the reported patient is a consequence of TMPRSS3 compound 
heterozygous c.208delC and c.579dupA mutations and in addition to that the patient is also a carrier of c.35delG in GJB2. Whether GJB2 mutations may modify the phenotype of ARNSHL in patients with biallelic TMPRSS3 mutations remains to be determined.

\section{Compliance with ethical standards}

Conflict of interest All authors declare no conflict of interest.

Open Access This article is distributed under the terms of the Creative Commons Attribution 4.0 International License (http://crea tivecommons.org/licenses/by/4.0/), which permits unrestricted use, distribution, and reproduction in any medium, provided you give appropriate credit to the original author(s) and the source, provide a link to the Creative Commons license, and indicate if changes were made.

\section{References}

1. Battelino S, Klancar G, Kovac J, Battelino T, Trebusak Podkrajsek K (2015) TMPRSS3 mutations in autosomal recessive nonsyndromic hearing loss. Eur Arch Otorhinolaryngol. doi:10.1007/ s00405-015-3671-0 [Epub ahead of print]
2. Gasparini P, Rabionet R, Barbujani G, Melçhionda S, Petersen M, Brøndum-Nielsen K, Metspalu A, Oitmaa E, Pisano M, Fortina P, Zelante L, Estivill X (2000) High carrier frequency of the 35delG deafness mutation in European populations. Genetic Analysis Consortium of GJB2 35delG. Eur J Hum Genet 8(1):19-23

3. Lechowicz U, Pollak A, Podgorska A, Stawinski P, Franke A, Petersen B et al (2015) Profile of TMPRSS3 mutation among Polish patients with nonsyndromic hearing impairment. In: European Human Genetics Conference. Glasgow, Scotland, United Kingdom. Eur J Hum 23(1)

4. Ben-Yosef T, Wattenhofer M, Riazuddin S, Ahmed ZM, Scott HS, Kudoh J, Shibuya K, Antonarakis SE, Bonne-Tamir B, Radhakrishna U, Naz S, Ahmed Z, Riazuddin S, Pandya A, Nance WE, Wilcox ER, Friedman TB, Morell RJ (2001) Novel mutations of TMPRSS3 in four DFNB8/B10 families segregating congenital autosomal recessive deafness. J Med Genet 38(6):396-400

5. Shahin H, Walsh T, Rayyan AA, Lee MK, Higgins J, Dickel D, Lewis K, Thompson J, Baker C, Nord AS, Stray S, Gurwitz D, Avraham KB, King MC, Kanaan M (2010) Five novel loci for inherited hearing loss mapped by SNP-based homozygosity profiles in Palestinian families. Eur J Hum Genet 18(4):407-413

6. Schäffer AA (2013) Digenic inheritance in medical genetics. J Med Genet 50(10):641-652

7. Morton CC, Nance WE (2006) Newborn hearing screening-a silent revolution. N Engl J Med 354(20):2151-2164 